\title{
Lymph Node Gene Expression Signature
}

National Cancer Institute

\section{Source}

National Cancer Institute. Lymph Node Gene Expression Signature. NCI Thesaurus. Code C120016.

A gene expression profile that indicates that a patient sample may have originated in or adopted the behavior of lymph node tissue. This gene signature may be associated with a better prognosis for melanoma patients. 